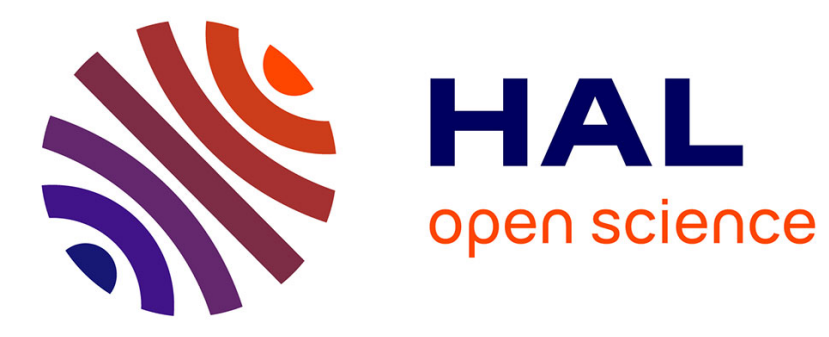

\title{
Long-run stability of money demand and monetary policy: the case of Algeria
}

Raouf Boucekkine, Mohammed Laksaci, Mohamed Touati-Tliba

\section{To cite this version:}

Raouf Boucekkine, Mohammed Laksaci, Mohamed Touati-Tliba. Long-run stability of money demand and monetary policy: the case of Algeria. 2021. halshs-03120699

\section{HAL Id: halshs-03120699 \\ https://shs.hal.science/halshs-03120699}

Preprint submitted on 25 Jan 2021

HAL is a multi-disciplinary open access archive for the deposit and dissemination of scientific research documents, whether they are published or not. The documents may come from teaching and research institutions in France or abroad, or from public or private research centers.
L'archive ouverte pluridisciplinaire HAL, est destinée au dépôt et à la diffusion de documents scientifiques de niveau recherche, publiés ou non, émanant des établissements d'enseignement et de recherche français ou étrangers, des laboratoires publics ou privés. 


\section{amse}

école d'économie d'aix-marseille aix-marseille school of economics

\section{Working Papers / Documents de travail}

\section{Long-run stability of money demand and monetary policy: the case of Algeria}

Raouf Boucekkine Mohammed Laksaci Mohamed Touati-Tliba 


\title{
Long-run stability of money demand and monetary policy: the case of Algeria
}

\author{
R. Boucekkine*, M. Laksaci** and M. Touati-Tliba ${ }^{* * *}$
}

January 2021

\begin{abstract}
We estimate the demand for money for monetary aggregates M1 and M2, and cash in Algeria over the period 1979-2019, and study its long-run stability. We show that the transaction motive is significant for all three aggregates, especially for the demand for cash, reflecting the weight of informal economy "practices". The elasticity of the scale variable is very close to unity for M2 and M1, and even equal to unity for cash demand (1.006). The elasticity of inflation is also significant for all three aggregates, although its level is higher in the case of cash demand (-6.474). Despite the persistence of certain financial repression mechanisms, interest rate elasticity is significant for all three aggregates, but higher for M1 and cash. The same observation is made for elasticity of the exchange rate, reflecting the effect of monetary substitution, especially for M1 and cash. Finally, our study concludes that the demand for money in terms of M1 remains stable, the same observation being confirmed for the M2 aggregate. However, the demand for fiat currency proves not to be stable. The consequences for the optimal design of monetary policy in Algeria are clearly stated.
\end{abstract}

Keywords: Monetary policy, money demand, long-run stability, resource-rich countries, Algeria, co-integration

JEL codes: E41, E42, E52, C13

\footnotetext{
We'd like to warmly thank Valantis Vasilakis and Michel Lubrano for details comments and suggestions. Boucekkine gratefully aknowledges support from the French National Research Agency Grants ANR-17-EURE0020.

${ }^{*}$ Corresponding author. Aix-Marseille University, CNRS, EHESS, Centrale Marseille, AMSE, Marseille, France. Corresponding member, IRES, UCLouvain, Belgium. Raouf.Boucekkine@univ-amu.fr

${ }^{* *}$ Ecole Supérieure de Banque, Alger Algeria. laksaci@bank-of-algeria.dz

*** Ecole Supérieure de Commerce d'Alger Algeria. m_touati@esc-alger.dz
} 


\section{Introduction}

Developments in the world economy since the Great Recession have shaken many of the certainties, or supposed certainties, relating to conduct of monetary policy and its implications for both macroeconomic stabilisation and the long term. As cogently argued by Benati et al. (2020), the very usefulness of even the most elementary monetary aggregates such as M1 as an anchor for monetary policy has recently been severely criticised. The argument is twofold, being mainly based on the observed properties of the (real) demand for money. The first objection, which is well known, is the volatility of such demand, which of course dates back to well before the Great Recession (see an earlier exploration in Fiess and MacDonald, 2001). Clearly such a feature reduces the scope for monetary policy based on standard aggregates as a stabilising instrument (typically, targets on the growth rates of M1 or M2). The second relates to the strong persistence of shocks to money demand, which is increasingly well understood as a result of recent theoretical work by many economists (including the excellent contribution from Alvarez and Lippi, 2014). The first argument has thus led to a shift in monetary policy (said to be optimal) from rules based on aggregates (M1 or M2) to rules based on interest rates, with a marked enthusiasm for the Taylor rule (see Davig and Leeper, 2007, for a generalisation). However, the much more recent fall in real interest rates to rock bottom levels close to the liquidity trap has brought into question the "Taylorian" paradigm and put monetary rules based on monetary aggregates back on track. Along these lines, Belongia and Ireland (2019) have recently tested the impact of different stabilisation rules based on the growth rate of monetary aggregates, over periods including episodes of interest rates at the floor level, on a DSGE model of the US economy. A similar job has been done by Barigozzi and Conti (2018) for the Euro area, they concluded pointing at "a possible evolution of the monetary pillar in the direction of pursuing financial stability ... after the exit from the prolonged period of unconventional monetary measures".

In this context, the question of the stability of long-run money demand becomes key, and this is precisely the purpose of the abovementioned study by Benati et al. (2020) as applied to the case of the US. While this issue is becoming so important again among the Western economies, it is, for a variety of reasons, every bit at least as crucial in resource-dependent countries. In a generic theoretical context, Torvik (2018) thus shows in elementary multi-sectoral models that stabilising the effects of external shocks on the price of the exported resource is more efficient in general through monetary policy. This is even truer in the case of a prolonged adverse shock such as the one experienced with oil prices since June 2014: expansive fiscal policies cannot claim to stabilise either in the short term or in the medium and long term. Monetary mechanisms (including exchange rate policy) should therefore be favoured in this case, whether or not combined with the appropriate fiscal measures. This makes the question of the stability of money demand in the long term even more crucial. 
Our study concerns Algeria, a country highly dependent on its natural resources. In addition to the generic aspects just discussed, this country has other special features making the question of the stability of the demand for money eminently more interesting. Firstly, like many other countries in the MENA region, and despite some progress, this country suffers from atrophied financial development, which reduces the scope and indeed the very relevance of stabilisation by Taylor-type rules. Indeed, it is unclear whether the fundamental problem of macroeconomic development or stabilisation in the MENA region relates solely to this channel of financial development, as the many sources of blockages are difficult to disentangle, as shown in the work by Ben Naceur et al. (2008). Furthermore, through a chain of circumstances, ranging from the budgetary treatment of the threat brought about by the Arab Spring to the very severe and persistent external oil shock of June 2014, and political-institutional circumstances over the last three years, all the macroeconomic indicators have been subject to considerable turbulence, and have received somewhat radical responses in terms of economic policy (especially the almost exclusive use of "money printing" for financing of the overall budget deficit and the economy). In so doing, the design of a genuine and appropriate monetary policy has become vital for the country.

Indeed, the vicissitudes of the Algerian economy, and particularly its monetary sphere, go back a few decades. Following the strong "monetarisation" of the Algerian economy during the $1970 \mathrm{~s}$, linked to the monetary financing of investments (bank credit automatically refinanced by the Central Bank) and monetisation of budget deficits, this latter phenomenon continued in a sustained manner during the $1980 \mathrm{~s}$, a decade marked by the drop in oil prices in 1986. The monetary reform of the early 1990s included an exit mechanism from the paradigm of fiscal dominance, but this was abandoned in 1992 and 1993 and then reintroduced to some extent as part of a stabilisation/structural adjustment package (1994-1998). The 2003 revision of the legal framework for money and credit again allows long-run monetary financing for the repayment of external public debt. Given the Algerian economy's dependence on natural resources and its vulnerability to oil price trends, the state of public finances significantly affects monetary developments. Following the persistent external oil shock of June 2014 and the deterioration of budget deficits in the absence of structural reforms, Algeria returned in autumn 2017 to the paradigm of fiscal dominance and its corollary, the monetisation of budget and quasi-budgetary deficits.

There is no doubt that not only is this policy of monetised budget deficits suboptimal, as indicated above with reference to the most widely accepted academic works (cf. Torvik, 2018), but that, in addition, due to the absence of structural reforms gradually eliminating dependence on the income from exported resources, especially fossil fuels, this policy can only lead to a debt trap (initially internal) in the medium term. 
Macroeconomic stabilisation is thus postponed and made more problematic. Thus, it is becoming urgent to tackle questions as elementary, and yet essential for the optimal design of monetary policy, now made vital, as the stability of the (long term) demand for money in Algeria. The least one can say is that while this type of research issue has received inadequate attention in recent years for the reasons we put forward at the beginning of the introduction, this is even truer for countries such as Algeria.

There are some studies devoted to money demand in Algeria, but they are very scarce. Indeed, only limited international research has been devoted so far to monetary issues in Arab countries, a notable exception being Hoffman and Tahiri (1994) and their study of money demand in Morocco. The few studies on money demand in Algeria (for example, by Bakhouche, 2006, or Koranchelian, 2003) have only focused on annual data, using the M2 aggregate. For the study by Koranchelian (2003), which estimates the long-run demand for money (1974-2001), before the phenomenon of excess liquidity on the money market, the elasticity of real GDP is 1.32 while that of inflation is -1.59 . Bakhouche's study (2006), for the period 1988-2004, leads to an estimate of money demand where only the elasticity of real GDP (1.278) is in line with expectations and significant. Both studies conclude that demand is stable in terms of M2. Moreover, the demand for money (M2) as estimated for fourteen countries in the MENA region, including two Maghreb countries, but not including Algeria, concludes that the demand for M2 is stable in almost all the countries of the region considered (Bahmani, 2008).

In our study, we argue that to gain a good understanding of monetary phenomena and the subsequent design of optimal monetary policy in Algeria, the demand for M1 and especially for cash deserves special attention, at least as much as the M2 aggregate, which was favoured in the few previous studies. Thus, the extent of the informal sector and informal practices in Algeria (including foreign exchange transactions) is such that it is practically imperative to include the demand for fiat currency in our study. In doing so, we shall be able to identify in greater detail the behavioural inflections of economic agents in the monetary sphere in this country. Similarly, since the M1 aggregate is potentially highly correlated with the credit variable in Algeria, it is important to clearly delineate the salient determinants of its demand and the stability of the latter over the long term.

We therefore study long-run demand for money in Algeria (1979-2019), for the three monetary aggregates (M2, M1 and fiat currency). The econometric estimation using the technique of co-integration through the Autoregressive Distributed Lagmodel(ARDL) shows that the elasticity of the scale variable (real GDP) takes the expected sign and is significantly close to unity, both for the aggregate M2 (1.019) and for the money supply 
M1 (1.040). For the fiat currency aggregate, it is equal to unity (1.006). The transaction motive is especially important with regard to the demand for cash that prevails as the sole method of payment for transactions in informal economy "practices", estimating the scale of which is not the subject of this study. The elasticity of inflation, which underlines the importance of "real assets" as an alternative to holding money, is also significant for all three aggregates, although its level is higher in the case of the demand for cash (-6.474). For the same monetary aggregates, exchange rate elasticity is significant and slightly higher in the case of demand for M1 (-0.196) and cash (-0.186), reflecting the currency substitution effect. Moreover, interest rate elasticity (treasury bill interest rate) is significant for M2, M1 and cash, but double for the latter two aggregates compared to M2. While confirming the stability of money demand in terms of M2, our study concludes that demand for M1 remains stable. This result is crucial in determining the growth objectives of monetary and credit aggregates still applicable, for optimal conduct of monetary policy in Algeria. However, the demand for fiat currency proves to be unstable over the long period under review, which is clearly a challenge, although expected, but highly significant, and to be addressed by the monetary authority (Money and Credit Council) and that country's central bank (Bank of Algeria).

This article is structured as follows. Section 2 proposes a review, in broad outline, of the main monetary developments between 1986 and 2020, which reflect monetary behaviours in Algeria, in parallel with evolution of the regulatory paradigm and the implementation of monetary and financial reform. Section 3 first deals with the specification of the money demand equation, drawing on the various relevant theoretical approaches, then documents all the data used before further exploring the estimation method based on the co-integration technique using the Autoregressive Distributed Lag model (ARDL) of Pesaran and Shin (1998) and Pesaran et al (2001). Section 4 reproduces and comments the results of the estimations conducted. Finally, some potentially useful lessons for the optimal design of monetary policy for the coming years are discussed in the conclusion (Section 5).

\section{Main monetary developments in Algeria (1986-2020)}

We draw on Figures 1 and 2, given below, to review the salient monetary developments in Algeria between 1986 and 2020, as also the underlying behavioural and regulatory inflections.

Following the first phase of "monetarisation" of the economy, monetisation of public sector financing needs and budget deficits continued in a sustained manner during the 1980 s, especially after the external shock of 1986. In the absence of fiscal adjustment, the 
drop by almost 50\% in revenue from oil taxation in 1986 led to a record overall budget deficit in 1988 (13.7\% of GDP against $10.7 \%$ in 1985 and $12.9 \%$ in 1986). As a consequence of correlative strong monetary expansion, the liquidity ratio (average M2/GDP) soared in 1986-87 (79\% on annual average), reflecting the acuity of repressed inflation. This had fuelled excess liquidity in the economy, especially since monetary policy played a passive role and the dinar was better fulfilling its functions as a unit of account and means of exchange than as a store of value. During the 1970s and 1980s, the paradigm of control of the public sector through the dinar (centralisation of investment and financing decisions, sectoral specialisation of public banks, etc.) had removed any active role of public enterprises in the demand for money, while they accumulated financial imbalances. Households' demand for money was almost exclusively for fiat currency, while demand from private enterprises, whose contribution to gross domestic product (GDP) remained extremely low, was much more for fiat currency than for scriptural money. Moreover, the negative real interest rates in the context of nominal administered rates was one of the main symptoms of the phenomenon of "financial repression".

With the advent of the monetary reform in 1990, the principle of separation between the issuance of central bank money and credit activity to the economy was ensured as the basis for a two-tier banking system. The dinar recovered all its functions and the monetary behaviours of economic agents, enterprises and households began to find expression in terms of the different motives for money demand. The Bank of Algeria has been granted broad prerogatives in the conduct of monetary policy, with the objective of stability of the currency's internal and external value. This has profoundly modified the paradigm of macroeconomic regulation of the Algerian economy, with the gradual reduction of the phenomenon of financial repression.

Figure 1

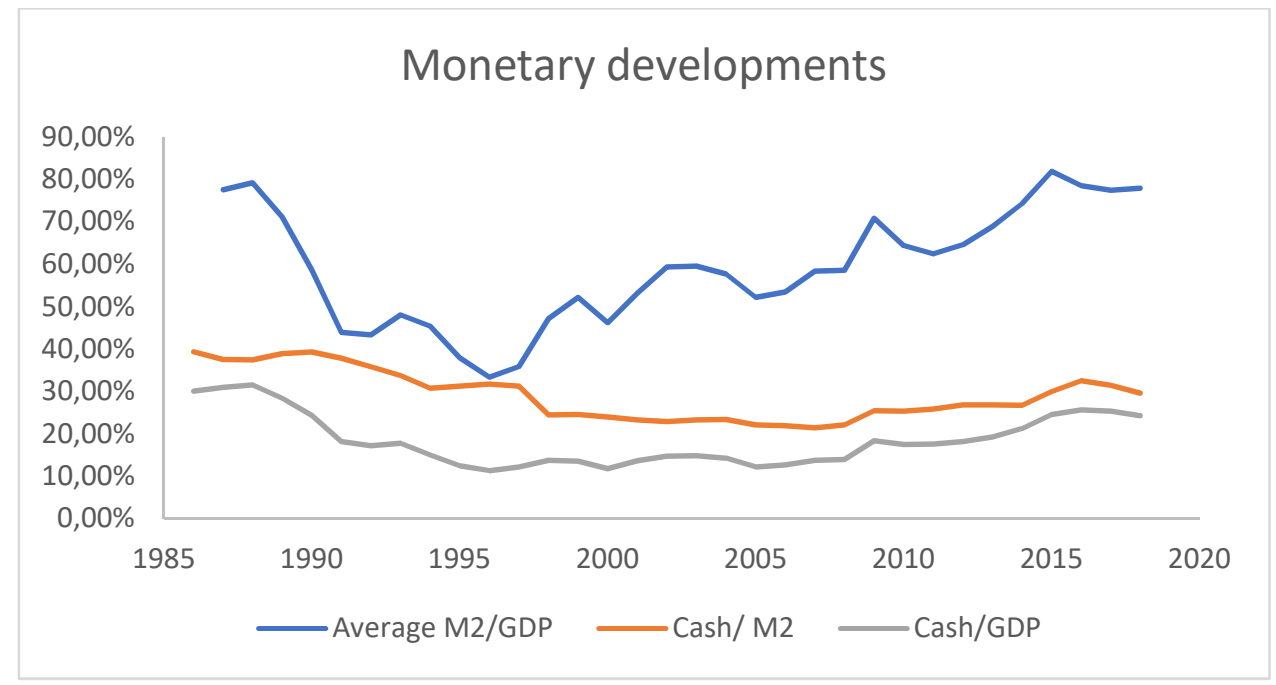


The appreciable results of the macroeconomic stabilisation implemented in 1991 (consolidation of public finances, consolidation of public banks and the implementation of other structural reforms), supported by the strong devaluation of the dinar, have allowed for a significant reduction of excess liquidity in the economy, in particular through tighter monetary policy. The liquidity ratio fell to $43 \%$ in 1991 , in a situation of overall Treasury surplus, after peaking at $79 \%$ in 1988 . However, as a result of budgetary expansion and monetisation of overall fiscal deficits, the liquidity ratio increased in $1992(48.0 \%)$ and 1993 (52.7\%). Growth in the monetary base (currency in circulation and bank deposits at the Bank of Algeria) was strong in 1992 (22.2\%) and $1993(27.4 \%)(8.9 \%$ in 1988$)$, but the currency in circulation/GDP ratio stabilised at nearly $18 \%$ over the years 1991 to 1993 (31.6\% in 1988). This reflected a cautious household demand for cash, in a situation of open and rising inflation (26.5\% in 1993 against $10.7 \%$ in 1989, year-on-year). The return in 1992/1993 to monetisation of the overall Treasury deficit in a situation of external debt crisis, with an external debt service ratio that had reached $100 \%$ in the first quarter of 1994 , had necessitated resorting to stabilisation and structural adjustment programmes, spread over four (4) consecutive years (1994 - 1998), supported by rescheduling of external debt.

Supported by the exchange rate adjustment and the reduction in the ratio of capital expenditure to GDP ( $7.3 \%$ in 1997 compared with $10.1 \%$ in 1989), consolidation of public finances in 1994-1995 had led to an overall Treasury surplus in 1996 and 1997. As a result of this significant recovery of public finances and the slowdown in money expansion in the sense of M2, at rates well below the "peak" of 1992 (24\%), the liquidity ratio stood at nearly $36 \%$ in 1997 . The implementation of stabilisation and structural adjustment programmes (1994-1998) rapidly absorbed the excess liquidity in the economy resulting from the strong monetary growth of 1992 and 1993. The reform of monetary policy instruments contributed to this, especially since it was combined with the liberalisation/adjustment of interest rates, particularly those applied by banks. The objective of positive credit interest rates in real terms was achieved towards the end of 1996, with an appreciable impact on the money demand behaviour of households and businesses.

Despite major stabilisation/adjustment efforts, the vulnerability of the Algerian economy to external shocks has remained high, judging by the return to imbalance in public finances in 1998. Budgetary consolidation measures (non-consumption of part of the capital budget, etc.) and the necessary correction of the exchange rate allowed the budget to be balanced in 1999, contributing to keeping inflation under control. This performance in terms of monetary stability in a situation of external shock (1998/1999) was supported by the fall in the ratio of currency in circulation to gross domestic product at $13.6 \%$ in 1999 compared with $24.3 \%$ in 1990 . The experience of 
stabilisation/adjustment between 1994 and 1998 shows that there was no significant "flight"away from the dinar and therefore strong monetary substitution (foreign currency versus the dinar). During the 1990s, households showed some caution in their demand for currency (cash) in a situation of open price inflation, as evidenced by the downward trend in the ratio of currency in circulation to GDP.

With the return to macroeconomic stability in 2000, the years 2001 to 2008 were marked by a sustained accumulation of financial savings by the State (with the Revenue Regulation Fund or FRR) in the form of deposits with the Bank of Algeria. These resources accumulated in the FRR rose from 5.6 per cent of GDP in 2000 to 24.4 per cent in 2005 and 38.8 per cent in 2008. This form of sterilisation contributed to mitigating the monetary effect of excess hydrocarbon resources, while the Bank of Algeria absorbed the excess liquidity on the money market that was inherent in the nonsterilised part of these resources. This aimed to contain the inflationary effect, while the aggregates M1 and M2 had increased significantly except in years of external shock.

After the strong monetary expansion recorded in 2001 (22.3\% in terms of M2), mainly due to the doubling of foreign assets, compared with 13\% in 2000, 2007 was also a year of high monetary growth $(24.2 \%)$ driven by the near doubling of deposits in the hydrocarbon sector. It was during this year that the ratio of currency in circulation/M2 got close to its historic low (21.4\%). This ratio has been structurally on the rise since 2008 , rising from $21.4 \%$ in 2007 to $33 \%$ in 2019 , peaking at over $35 \%$ in 2020 . This confirms the preference of households and several "economic operators" for fiat currency (cash), whereas the aim of the payment systems (electronic clearing and the system for high value and urgent payments) set up in 2006 is to promote the use of scriptural money instruments (cheques, transfers, bank cards, etc.).

The magnitude of the external shock in 2009 was such that deposits in the hydrocarbon sector contracted by $50 \%$ and the rate of expansion of M2 fell sharply $(3.1 \%$ compared with $16 \%$ in 2008). This resulted in a rebound in currency in circulation relative to the M2 aggregate to $25.5 \%(22.1 \%$ in 2008$)$.

After the external shock of 2009, the external financial position improved between 2010 and 2013. During this period, the year 2011 saw strong monetary growth (19.9\%) in terms of M2, fuelled by less sterilisation (allocation of resources - net - to the Revenue Regulation Fund). The expansion of fiat currency (22.5\%), following the significant increase in the wage bill in the State budget, was more vigorous.

The two years preceding the external shock of 2014 recorded a deceleration in the rates of expansion of M2, $10.9 \%$ in 2012 and $8.4 \%$ in 2013 , correlative to the rates of contraction of deposits deriving directly from hydrocarbon export revenues. Over the last five years, the rapid erosion of foreign exchange reserves has had a monetary "destructive" effect, whereas their sustained accumulation was the main source of monetary expansion. 
This has revealed a worsening of the Algerian economy's vulnerability to external shock, especially as the overall Treasury deficit has persisted since 2009. Also, the significant widening of the overall Treasury deficit between 2014 and 2016 to $8.0 \%$, $15.7 \%$ and $12.6 \%$ of GDP, respectively, has led to a sharp contraction in the Treasury's financing capacity. Indeed, the outstanding resources of the FRR relative to GDP stood at $25.6 \%$ at the end of $2014,12.4 \%$ at the end of $2015(40.4 \%$ in 2010$)$ and $4.5 \%$ in 2016. The deterioration in public treasury from the second half of 2016 , which worsened in 2017, necessitated recourse to monetary financing from the Bank of Algeria as from November 2017.

The resources provided by recourse to monetary financing, part of which was used to finance the Treasury's overall deficit, contributed significantly to the resumption of monetary expansion. This new feature of the monetary situation materialised through the rate of monetary growth in the sense of the M2 aggregate in 2017 (8.38\%) compared with rates close to zero in $2016(0.82 \%)$ and $2015(0.13 \%)$ and was historically low. As a result, by the end of 2015 , the money supply represented $82.0 \%$ of GDP, a rate that is still relatively limited compared to the rates in comparable emerging countries. As for the monetary aggregate M1, its expansion was slightly higher (9.1\%), after a contraction of $3.3 \%$ in 2015 followed by a slight increase in 2016 (1.6\%). The resumption of monetary expansion in 2017 did not yet fully reflect the effect of the creation of base money resulting from the direct acquisition by the Bank of Algeria of securities issued by the Treasury, as part of the new monetary financing "paradigm". For the year 2018, the sustained monetisation of domestic public debt contributed substantially to fuelling monetary growth, at a double-digit rate (11.10\%) for the M2 aggregate, contrary to the evolution of the last three years following the external shock in 2014 .

While, since 2015, the downward trend in net foreign assets has had a monetary "destruction" effect in the sense of the M2 aggregate, the sharp contraction recorded in this respect during 2019 resulted in a decrease by about $1 \%$ in the money supply (M2) in a situation of shock on credits to the economy, while monetary financing in favour of the Treasury reached an outstanding amount of 6,556.2 billion dinars (about 32\% of GDP). Conversely, the level of currency in circulation, which normally indicates households' payment habits, remains very high and significantly inceasing compared to gross domestic product (26.8\% at the end of 2019 against $21.2 \%$ at the end of 2014 and $17.5 \%$ in 2010), confirming the increase in transactions in the informal economy. The level of this ratio and its structural upward trend in Algeria contrasts significantly with the cash situation in the emerging economies that are members of the CPMI (Committee on Payments and Market Infrastructures). In these latter, currency in circulation stood at 8 per cent relative to gross domestic product in 2016 (7.2 per cent in 2000) (Bech et al. , 2018). 
Figure 2

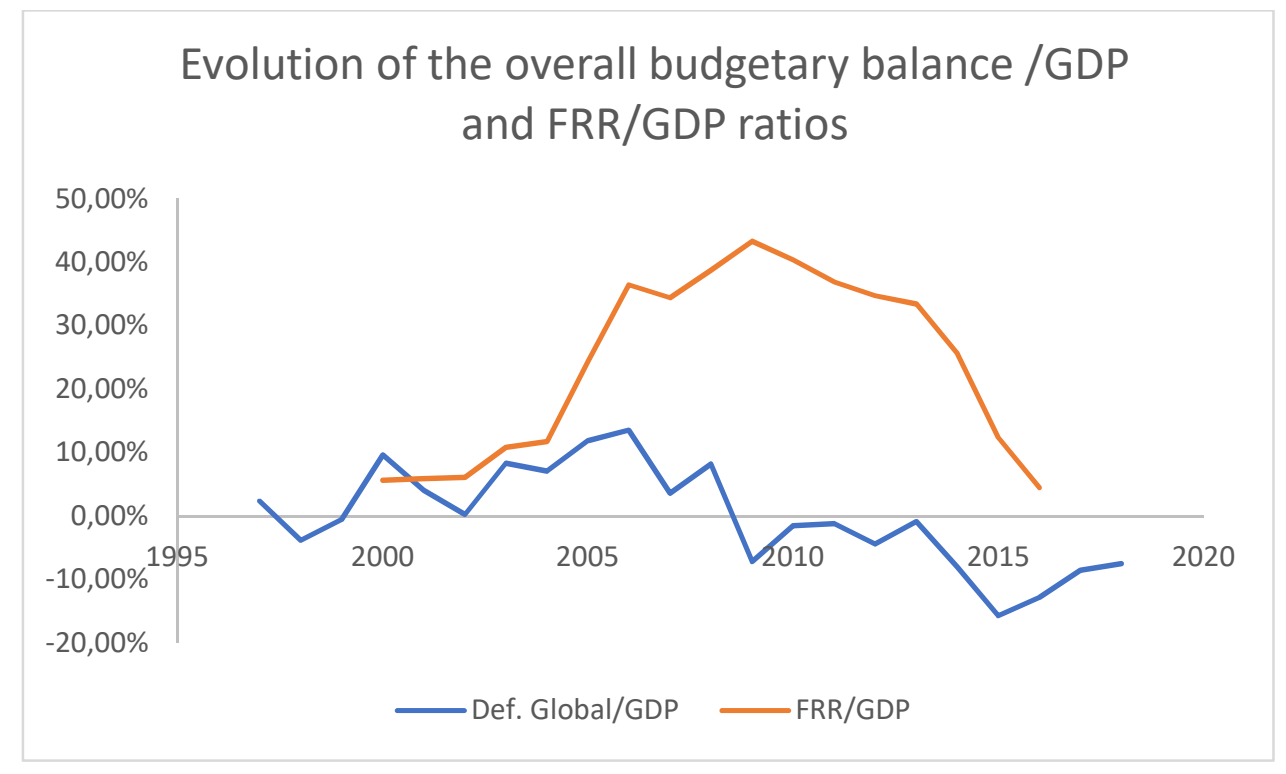

\section{Methodology}

\subsection{Specification of the long-run empirical relationship}

In empirical specifications of the money demand equation, particularly in emerging economies (Sriram, 1999; 2000), thescale variable is most often represented by real GDP to cater for the transaction motive, even though the precautionary motive is also largely related to revenue. In the precautionary money demand approach, holding of cash balances aims at a lower exposure to illiquidity risk, but at the same time renouncinginterest income. Deriving from the Keynesian contribution to money demand theory, the speculative motive stems from the preference for liquidity, especially when interest rates are very low.

Among the post-Keynesian theoretical developments in money demand (Baumol, 1952, Tobin, 1956 and 1958, Friedman, 1956 and 1977), the cash-in-advance models approach, coupled with expected inflation as opportunity cost and monetary substitution, is the appropriate one for specification of money demand in emerging and developing economies. In developing economies where the financial sector is poorly developed (limited substitution between currency and other financial assets, regulated interest rates, etc.), the expected inflation rate is practically the most widely used variable as an opportunity cost of holding money. In those economies with high and/or chronic inflation, the expected inflation rate is not just appropriate to the money demand equation, but it is also important to introduce an adequate exchange rate variable to capture the effect of monetary substitution. 
Real GDP is the scale variable for specification of the long-run money demand equation for Algeria. Three other explanatory variables are taken into account: the interest rate on treasury bills as well as the inflation rate as opportunity costs, and the exchange rate (the Algerian dinars against one US dollar). A multiplicative specification for the longrun money demand relationship is adopted. This specification is general enough to encompass several alternative theories, given anappropriate choice of scale variable and opportunity costs. It is also implicit in most empirical formulations that express the logarithm of real money demand as a linear function of the logarithm of real GDP and opportunity costs, including the interest rate.

$$
\left(\frac{M_{t}}{C P I_{t}}\right)=C_{0}\left(\frac{G D P_{t}}{C P I_{t}}\right)^{\alpha}\left(1+\text { TBrate }_{t}\right)^{\beta}\left(1+\text { Infrate }_{t}\right)^{\delta}\left(\text { Exchrate }_{t}\right)^{\gamma} \exp \left(\varepsilon_{t}\right)
$$

The logarithmic transformation of the previous relationship gives the expression :

$$
\ln M r_{t}=c_{0}+\alpha \ln G D P r_{t}+\beta \ln T B R_{t}+\delta \ln \operatorname{In} f_{t}+\gamma \ln E x c h_{t}+\varepsilon_{t}
$$

Where $\ln M r_{t}=\ln \left(\frac{M 2_{t}}{C P I_{t}}\right)\left(\operatorname{or} \ln M r_{t}=\ln \left(\frac{M 1_{t}}{C P I_{t}}\right)\right.$ or $\left.\ln M r_{t}=\ln \left(\frac{\operatorname{Cas} t}{C P I_{t}}\right)\right)$;

$$
\ln G D P r_{t}=\ln \left(\frac{G D P_{t}}{C P I_{t}}\right) ; \ln T B R_{t}=\ln \left(1+\text { TBrate }_{t}\right) ; \ln \operatorname{Inf} f_{t}=\ln \left(1+\text { Infrate }_{t}\right)
$$

andlnExch $_{t}=$ lnExchrate $_{t}$;

It is expected that $\alpha$ be positive and $\beta$ and $\delta$ negative. However, $\gamma$ could be positive or negative (Arango and Nadiri, 1981; Bahmani-Oskooee and Poorheydarian, 1990).

This specification allows all coefficients to be interpreted as elasticities. It should be noted that the estimated values of parameters $\beta$ and $\delta$ would not be significantly different from those obtained from a specification that introduces rates TBrate and Infrate instead of $\ln (1+$ TBrate $)$ andln $(1+$ Infrate $){ }^{1}$

\footnotetext{
${ }^{1}$ When $x$ is small enough $\ln (1+x) \approx x$.
} 


\subsection{Data}

The data used are annual data for the period 1979-2019. The sources arethe Bank of Algeria for variables M2, M1 and fiat money(cash), the World Bank (WBI) for GDP and CPI variables (base year 2010) and the IMF for treasury bill rates (TBrate). ${ }^{2}$

The following table presents summarystatisticsof the variables used.

Table 1/ Summary statistics

\begin{tabular}{lcccc}
\hline Variable & Mean & Std. Dev. & Min & Max \\
\hline $\operatorname{lnGDPr}$ & 10.98 & 0.64 & 10.03 & 11.87 \\
$\operatorname{lnM} 2 \mathrm{r}$ & 10.51 & 0.73 & 9.56 & 11.64 \\
$\operatorname{lnM} 1 \mathrm{r}$ & 10.16 & 0.70 & 9.17 & 11.28 \\
$\operatorname{lnCashr}$ & 9.31 & 0.64 & 8.46 & 10.49 \\
$\operatorname{lnExch}$ & 3.43 & 1.24 & 1.34 & 4.78 \\
$\operatorname{lnTBR}$ & 0.0425 & 0.042 & 0.002 & 0.153 \\
$\ln \mathrm{Inf}$ & 0.0829 & 0.071 & 0.003 & 0.275 \\
\hline
\end{tabular}

Figure 3 below shows graphs of variables $\operatorname{lnGDPr}$, $\operatorname{lnM} 2 \mathrm{r}, \operatorname{lnM} 1 \mathrm{r}$ and $\operatorname{lnC}$ ashr.

Figure 3

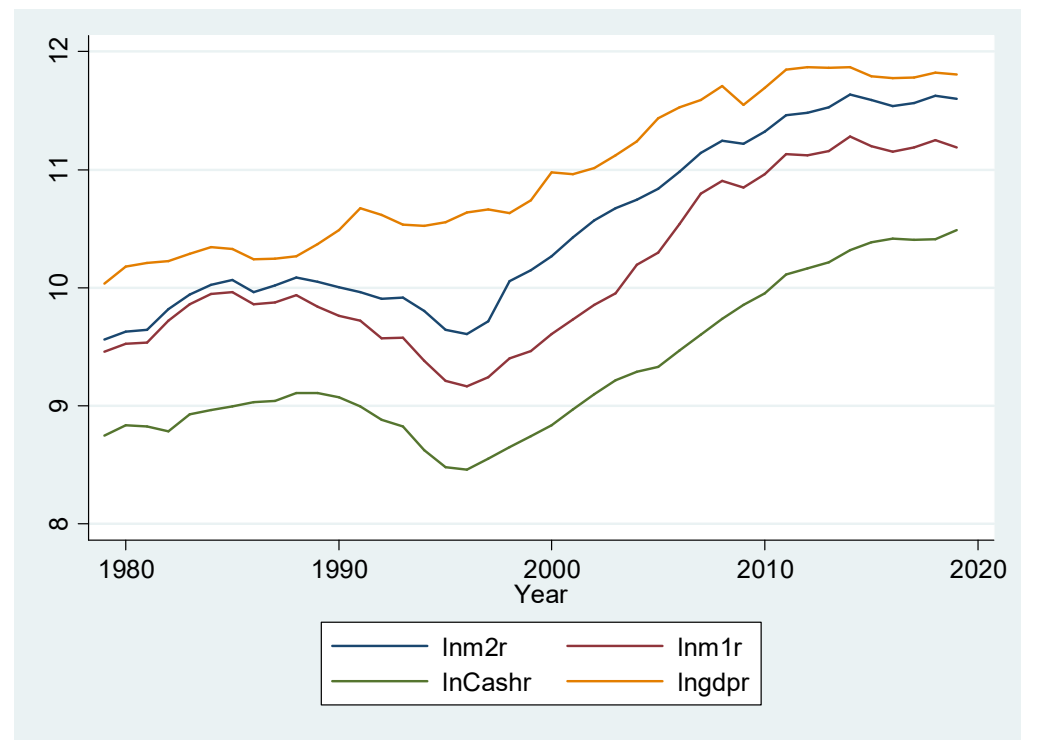

${ }^{2}$ Note that the TBrate rates for 4 years $(79,95,96$ and 97$)$ are missing. The rate for 1979 is replaced by the constant rate for the period 1980-1990. To impute the other three missing values from the "TBrate" series, we use the average of two estimates. The first is based on the average annual growth rate of the series for the period 1994-1998 and the second estimate uses the annual growth rates of the "Deposit interest rate" series. The deposit interest rate series is only available for the period 1994-2019. It shows, for this period, a strong correlation with TBrate (0.97). 
Figure 4 below shows graphs of variables TBrate and Infrate.

Figure 4

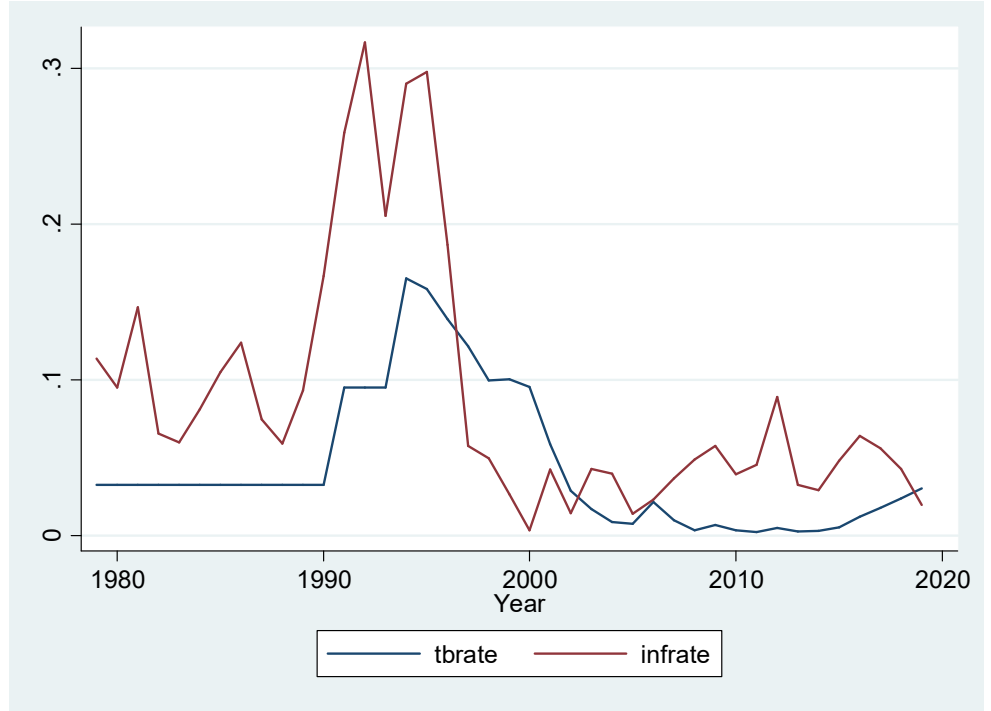

\subsection{Estimation method}

Over the last three decades, econometrics has beenmarked by the development of the co-integration theory, which allows the long-run equilibrium relationship between two or more time series to be detected. Based on the seminal work of Granger (1986) and Engle \& Granger (1987), error-correction (EC) models have been developed mainly by Johansen (1988, 1991) and Johansen \&Juselius (1992). Subsequently, the Autoregressive Distributed Lag model(ARDL) was developed by Pesaran \& Shin (1997) and Pesaran et al. (2001).

Since their development, EC modelshave been widely used to estimate the money demand relationship. One feature of the modelling process is that the long-run equilibrium is specifiedby economic theory while the short-term dynamics are dictated by data (Sriram, 1999). Contrary toearlier money demand studies that used Johansen's approach (Johansen 1988, 1991; Johansen \& Juselius, 1992), many relatively recent works increasingly use the ARDL approach (Enisan Akinlo, 2006; Bahmani-Oskooee \& Wang 2007; Tang, 2007; Bahmani, 2008). ${ }^{3}$

In the present work, estimation of the long-run (real) money demand relationship for M2, M1 and Cash is conducted using the ARDL approach. An ARDL EC-type model

${ }^{3}$ See Sriram (1999) for a literature review of previous studies. 
(Pesaran \& Shin, 1998) is estimated and cointegration is verified using the bounds test which is particularlyappropriate"when it is not known with certainty whether the underlying regressors are trend stationary or first-order stationary"(Pesaran et al., 2001).

In addition to providing robust results in small samples, one of the main advantages of this approach is that the test for the existence of a relation between the variables at the levels is applicable regardless of whether the underlying regressors are $\mathrm{I}(0)$, I(1) or mutually cointegrated (Pesaran et al., 2001). However, the bounds test is based on the assumption that the variables are $\mathrm{I}(0)$ or $\mathrm{I}(1)$. Therefore, before applying it, unit root tests need to be conducted to ensure that the variables are not I(2) and avoid spurious results.

The econometric specification of the ARDL model (p, q1, q2, q3, q4) is given by the following expression:

$$
\begin{gathered}
\ln M r_{t}=a_{0}+\sum_{i=1}^{p} a_{i} \ln M r_{t-i}+\sum_{i=0}^{q_{1}} b_{i} \ln G D P r_{t-i}+\sum_{i=0}^{q_{2}} c_{i} \ln T B R_{t-i}+ \\
\sum_{i=0}^{q_{3}} d_{i} \ln \operatorname{In} f_{t-i} \sum_{i=0}^{q_{4}} e_{i} \ln E x c h_{t-i}+u_{t}(1)
\end{gathered}
$$

Re-parameterisation in the EC form is given by the expression:

$$
\begin{aligned}
& \Delta \operatorname{lnM} r_{t}=c_{0}-\theta\left(\operatorname{lnMr}_{t-1}-\alpha \operatorname{lnGDPr_{t}}-\beta \ln T B R_{t}-\delta \operatorname{lnInf} f_{t}-\gamma \ln E x c h_{t}\right)+ \\
& \sum_{i=1}^{p-1} \varphi_{i} \Delta \ln M r_{t-i}+\sum_{i=0}^{q_{1}-1} \alpha_{i} \Delta \ln G D P r_{t-i}+\sum_{i=0}^{q_{2}-1} \beta_{i} \Delta \operatorname{lnTBR} R_{t-i}+\sum_{i=0}^{q_{3}-1} \delta_{i} \Delta \ln \operatorname{In} f_{t-i}+ \\
& \sum_{i=0}^{q_{4-1}} \gamma_{i} \Delta \ln \operatorname{In} f_{t-i}+\varepsilon_{t}
\end{aligned}
$$

In this EC form, the bracketed expression states the long-run equilibrium relationship where the coefficient of each independent variable represents the equilibrium effect of the indicated variable on the dependent variable. Meanwhile, parameter $\theta$, designates the speed of adjustment. It measures how quickly a deviation from the equilibrium relationship is corrected. The other parameters are coefficients that take into account other short-term fluctuations.

For the ARDL EC model (Pesaran and Shin, 1998; Pesaran, Shin \& Smith, 2001), as for the Johansen'sEC model $(1988,1990)$, the methodological steps applied are as follows:

- Determination of lag order(according to Akaike information criterion (AIC) or Schwarz's Bayesian information criterion (BIC));

- Series stationarity tests (Augmented Dickey-Fuller (ADF)unit root tests);

- Co-integration boundstests(Pesaran et al., 2001) for ARDL;

- Estimation of an ARDLEC model;

- Tests for stability of the long-run relation (Tests of CUSUMand CUSUM2 by Brown, Durbin \& Evans (1975)); 
- Goodness of fit, robustnessand diagnostic tests.

\section{Estimating and testing money demand relations (M2, M1 and Cash)}

\section{Determining lag order}

For each series, the lag orderhas to be determined for unit root tests as well as for model selection. To implement the unit root ADF test, the lag orders of the underlying autoregressive processes generating the data are required. If the lag orderfor a variable is too great, the test'spower may be impaired. Conversely, if it is too small, the remaining autocorrelation can bias the test. For testing purposes, the AIC criterion is strongly recommended as the lag order selection statistic. However, as a suitable model selection criterion, the optimal lag orders $\mathrm{p}$ and $\mathrm{q}$ can be obtained on the basis of the AIC or BIC criterion (Kripfganz \& Schneider, 2018).

To determine lag orders in the present articlewe use the AIC criterionfor testingpurposesand BIC criterionfor model selection.Columns 2 of Tables 2 and 3 below respectively show the lagorders of the series at level and at first difference according to AIC for the alternative underlying autoregressive processes (cases ofno constant, constant, drift and trend respectively).

\section{ADF stationarity tests}

The results of the ADF tests for series at level areshown in Table 2 for the underlying autoregressive process (cases) and order of lagindicated. They show that the three monetary aggregates as well as the scale variable are not stationary at level for all cases. Similarly, the variables $\ln$ TBR, $\ln I n f$ and $\operatorname{lnExch}$ are not stationary at level except in case 3 (drift).

Table 2/ Results of series unit root ADF tests at level

\begin{tabular}{lccccccccc}
\hline & Case & No constant & \multicolumn{3}{c}{ Constant } & \multicolumn{2}{c}{ Drift } & \multicolumn{3}{c}{ Trend } \\
\hline Var. & AIC lag & t stat & CV & t stat & CV & t stat & CV & t stat & CV \\
\hline lnM2r & 2 & 1.658 & -1.95 & -0.578 & -2.964 & -0.578 & -1.691 & -1.617 & -3.548 \\
lnM1r & 4 & 0.32 & -1.95 & -1.102 & -2.969 & -1.102 & -1.697 & -3.061 & -3.556 \\
lnCashr & 2 & 1.255 & -1.95 & -0.26 & -2.964 & -0.26 & -1.691 & -1.638 & -3.548 \\
lngdpr & 1 & 2.22 & -1.95 & -0.486 & -2.961 & -0.486 & -1.688 & -2.049 & -3.544 \\
lnTBR & 4 & -1.171 & -1.95 & -1.88 & -2.969 & $-1.88^{* *}$ & -1.697 & -2.205 & -3.556 \\
lnInf & 1 & -1.42 & -1.95 & -1.976 & -2.961 & $-1.976^{* *}$ & -1.688 & -2.417 & -3.544 \\
lnExch & 4 & 0.405 & -1.95 & -1.756 & -2.969 & $-1.756^{* *}$ & -1.697 & -1.892 & -3.556 \\
\hline CV: critical values at 5\% level; ** indicates significant. & \multicolumn{3}{c}{}
\end{tabular}


Furthermore, at the first difference, the results in Table 3 indicate that all variables are stationary for cases 3 (drift) and 1 (no constant) except for $\operatorname{lnExch}$ in case 1. For the two other cases, the results are mixed.

Table 3/ Results of the series unit root ADF tests at first difference

\begin{tabular}{|c|c|c|c|c|c|c|c|c|c|}
\hline & Case & noconstant & & Constant & & Drift & & trend & \\
\hline Var. & AIC lag & $\mathrm{t}$ stat & $\mathrm{CV}$ & t stat & $\mathrm{CV}$ & t stat & $\mathrm{CV}$ & t stat & $\mathrm{CV}$ \\
\hline $\operatorname{lnM} 2 r$ & 1 & $-2.768 * *$ & -1.95 & $-3.316^{* *}$ & -2.964 & $-3.316 * *$ & -1.69 & -3.251 & -3.548 \\
\hline $\ln M 1 r$ & 1 & $-2.459 * *$ & -1.95 & $-2.656^{*}$ & -2.964 & $-2.656 * *$ & -1.69 & -2.609 & -3.548 \\
\hline lnCashr & 1 & $-1.891^{*}$ & -1.95 & -2.287 & -2.964 & $-2.287 * *$ & -1.69 & -2.448 & -3.548 \\
\hline lngdpr & 0 & $-4.548 * *$ & -1.95 & $-5.285^{* *}$ & -2.961 & $-5.285 * *$ & -1.687 & $-5.211 * *$ & -3.544 \\
\hline $\operatorname{lnTBR}$ & 3 & $-2.415 * *$ & -1.95 & -2.374 & -2.969 & $-2.374 * *$ & -1.696 & -2.34 & -3.556 \\
\hline $\operatorname{lnInf}$ & 0 & $-5.763 * *$ & -1.95 & $-5.697 * *$ & -2.961 & $-5.697 * *$ & -1.687 & $-5.635^{* *}$ & -3.544 \\
\hline $\operatorname{lnExch}$ & 3 & -1.389 & -1.95 & -1.76 & -2.969 & $-1.76^{* *}$ & -1.696 & -2.02 & -3.556 \\
\hline
\end{tabular}

The results of case 3 (drift) suggest use of the ARDL approach (Pesaran \& Shin, 1998; Pesaran et al., 2001) while the results of case 1 (no constant) may suggest use of either the ARDL or the Johansen approach since the latter requires the variables to be $\mathrm{I}(1)$. However, it is unlikely that the real processes generating the variables are all of the same nature. The ARDL model is probably better suited to deal with uncertainty as to the nature of the realgenerating processesI(1) or $\mathrm{I}(0)$.

\section{Model selection}

Formodel selection, the BIC lag selection criterion is applied throughout. To model the deterministic component of the ARDL ECM model, three options are available: no constant (no constant and no trend), constant (constant and no trend) and trend (constant and trend). By comparing the results of these three options, itappears that the no constant option has a better goodness of fit, especially for the M1 and Cash models. Moreover, when applied to both M1 and Cash aggregates, the trend option produces a nonsignificant coefficient of the trend variable. Similarly, when applied to the two M2 and cashaggregates, the constant option produces anon-significant constant.

\section{Co-integration bounds tests}

Since the BIC criterion tends to favour the most parsimonious models in relation to the AIC criterion, we choose to use BIC statistics to select models with fewer parameters to estimate as we have a limited number of observations. However, for the tests of Pesaran 
et al (2001), we use AIC to select models to be tested with more lag terms in order to avoid biases due to autocorrelation.

The optimal lagorders $\mathrm{p}$ and $\mathrm{q}$ obtained using the selection criteria of the AICand BIC models are shown in Table 4 for the no constantcase. For all the selected models, the results of the co-integration limit test of Pesaran et al. (2001) indicate the existence of long-run co-integration relationships between money demand (lnM2r, $\operatorname{lnM} 1 \mathrm{r}, \operatorname{lnCashr}$ ) and the variables $\operatorname{lnGDPr}, \ln T B R, \ln I n f$ and $\operatorname{lnExch}$. The significance of the negative coefficient on the speed of adjustment towards long-run equilibrium is confirmed.

Table 4/ Summary of results of ARDL bounds co-integration tests for selected models

\begin{tabular}{lcccccc}
\hline Var. & no constant , AIC & $\mathrm{F}$ & $\mathrm{t}$ & no constant, BIC & $\mathrm{F}$ & $\mathrm{T}$ \\
\hline M2 & ARDL $(3,4,4,1,4)$ & 10.976 & -4.061 & ARDL $(3,2,0,1,0)$ & 12.343 & -6.256 \\
M1 & ARDL $(3,2,3,1,3)$ & 9.668 & -6.069 & ARDL $(1,0,2,0,3)$ & 24.973 & -7.653 \\
Cash & ARDL $(1,1,0,2,4)$ & 43.401 & -5.088 & ARDL $(1,1,0,0,0)$ & 50.169 & -5.202 \\
\hline & Critical value at 1\%. & 4.44 & -4.23 & Critical value at $1 \%$. & 4.44 & -4.23 \\
\hline
\end{tabular}

\section{Estimation of long-runrelationships}

According to the BIC criterion, the money demand models for M2, M1 and cash take the forms $\operatorname{ARDL}(3,2,0,1,0), \operatorname{ARDL}(1,0,2,0,3)$ and $\operatorname{ARDL}(1,1,0,0)$ respectively. The following Table5 provides estimates of the long-run relationship for the three aggregates.

Table 5 / Results of long-run relationships for ARDL models with no constant

\begin{tabular}{llll}
\hline BIC & $\operatorname{lnM} 2 \mathrm{r}$ & $\operatorname{lnM} 1 \mathrm{r}$ & LnCashr \\
\hline noconstant & Coef. (Std. Err.) & Coef. (Std. Err.) & Coef. (Std. Err.) \\
\hline EC & $-0.456(0.073)^{* * *}$ & $-0.334(0.044)^{* * *}$ & $-0.127(0.024)^{* * *}$ \\
\hline $\operatorname{lnGDPr}$ & $1.019(0.01)^{* * *}$ & $1.040(0.013)^{* * *}$ & $1.006(0.029)^{* * *}$ \\
$\ln \mathrm{TBR}$ & $-1.932(0.699)^{* * *}$ & $-4.494(0.885)^{* * *}$ & $-4.220(1.342)^{* * *}$ \\
$\ln \mathrm{nnf}$ & $-2.779(0.654)^{* * *}$ & $-3.639(0.958)^{* * *}$ & $-6.474(1.758)^{* * *}$ \\
$\operatorname{lnExch}$ & $-0.063(0.02)^{* * *}$ & $-0.196(0.03)^{* * *}$ & $-0.186(0.0520)^{* * *}$ \\
\hline
\end{tabular}

The results of the estimation of the long-run equilibrium relationship for M2 show that the elasticities take their expected signs and are significant. The estimated elasticity of the scale variable is significantly close to unity (1.019). Indeed, an increase in real GDP of $1 \%$ implies an increase in demand for M2 of $1.019 \%$. The elasticity of inflation, which underlines the importance of "real assets" as an alternative to holding money, is high (-2.779). When the price level increases by $1 \%$, demand for M2 falls by $2.779 \%$. Similarly, the negative sign for the interest rate variable (treasury bills) and the significant degree of its estimated coefficient indicate the high sensitivity of demand for M2 to the interest rate as an opportunity cost. 
Moreover, the negative sign of the exchange rate elasticity confirms the substitution effect, but with low sensitivity of demand for $\mathrm{M} 2$ to the exchange rate. When the dinar depreciates (relative to the US\$) by $1 \%$, demand for M 2 falls by just $0.063 \%$. The adjustment speed parameter is negative and significant. This indicates the convergence of the variables towards the long-run equilibrium relation where $45.6 \%$ of the adjustment is completed during the year; the convergence towards equilibrium takes almost 27 months.

These results are to some extent in line with the rare studies on money demand in Algeria, at least for one or two explanatory variables (scale variable and inflation). For the study by Koranchelian (2003), which estimates long-run money demand (M2) for the period 1974-2001, before the phenomenon of excess liquidity on the money market, the coefficient of real GDP is 1.32 and that of inflation is -1.59. Meanwhile, Bakhouche's study (2006) for the period 1988-2004 leads to an estimate of long-run money demand (M2) where only the elasticity of real GDP (1.278) is in line with expectations and significant.

For the M1 aggregate, the results of the estimation of long-run money demand, for the same period and the same explanatory variables, show that elasticities take their expected signs and are all significant. The estimated elasticity of the scale variable is significantly close to unity (1.040). The significance of real assets as an alternative to owning money is confirmed, especially as the elasticity of inflation (-3.639) is higher than in the case of M2. Indeed, when the price level increases by $1 \%$, demand for M1 decreases by $3.639 \%$. Similarly, compared to M2, the estimated coefficient for the yield on treasury bills is very high (twice as high) (-4.494), confirming the importance of its role as an opportunity cost for M1 demand. The liberalisation of lending rates during the stabilisation/adjustment period and the control of inflation from the beginning of the 2000 s contributed to this. Finally, the negative sign of exchange rate elasticity indicates that when the dinar depreciates (against the US dollar) by 1\%, demand for M1 declines by $0.196 \%$. The substitution effect is thus greater than in the case of the M2 aggregate, which includes foreign currency deposits. The adjustment speed parameter $(-0.334)$ indicates that convergence to equilibrium takes about three years, longer than for the M2 aggregate. Indeed, compared to the M1 aggregate, M2 includes foreign currency deposits which are stable resources returned to the Bank of Algeria.

The estimation of the long-run equilibrium relationship for the demand for cash shows that elasticities take their expected signs and are all significant. The estimated elasticity of scale variable is equal to unity (1.006), despite the efforts of financial liberalisation and development of book-money means of payment. Also, the motive for transactions is a determining factor in holding cash. Furthermore, the results yet again confirm the 
importance of real assets as an alternative to holding cash balances, since their demand falls by more than $6 \%$ when the price level rises by $1 \%$. This very high level (6.474) of inflation elasticity, especially compared to the aggregates M2 and M1, argues in favour of holding alternative assets, especially real assets, and for less hoarding. The estimated coefficient for the yield of treasury bills is as high (-4.220) as that estimated for M1, reflecting the significance of this opportunity cost for the demand for cash. The liberalisation of interest rates that became positive in real terms following stabilisation/adjustment contributed to this to a certain extent. Finally, the negative sign of exchange rate elasticity indicates that when the dinar depreciates (against the US dollar) by $1 \%$, the demand for cash decreases by $0.186 \%$. The substitution effect is relatively greater in the case of cash and M1 as compared with M2. A much slower convergence towards equilibrium (by almost eight years), since the estimated speed of adjustment parameter is -0.127 , characterises the demand for cash.

In the Algerian economy, where the holding of "cash" is de facto a prerequisite for conducting a large share of transactions on goods and services, as in the case of the "cash-in-advance model", the longer period of convergence towards equilibrium (almost eight years) is indicative of the "practices" of the informal economy where cash prevails as the sole method of payment.

Contrary to the evolution recorded in several emerging and developing economies with regard to the use of more numerous electronic payment instruments (payment cards, mobile payment, etc.) (Bech et al., 2018), the monetary behaviour of households and a large number of economic operators has thwarted the objective sought through modernisation of the system of small sum payments in Algeria from 2006 onwards. Their almost exclusive and persistent recourse to fiat currency as a means of payment and store of value is largely due to the "trap" of the cash payment method and the extent of "hoarding", especially through holding large denomination notes. To some extent, this undermines the role of interest rates as an opportunity cost for holding cash.

\section{Estimation of short-term dynamics}

Taking into account the short-term fluctuations in modeling money demand is important for a good estimation of the long run relationship. The failure to find stable long run demand for money could be due to ignoring the short-run adjustment process (Laidler, 1993).

The main results of short-term dynamic for M2, M1 and Cash are summarized in table 6.For all three aggregates, theresults show that the short-term effects of real GDP and inflation are opposite to the long-run equilibrium effects. For example, an increase in the price 
level has the long-run effect of decreasing demand for M2, while the short-run direction of influence is the opposite.

Table 6/ Results of short-term dynamics for ARDL models with no constant

\begin{tabular}{|c|c|c|c|c|c|c|c|c|c|}
\hline Lag & 0 & 1 & 2 & Lag & 0 & 1 & 2 & Lag & 0 \\
\hline$\Delta \ln M 2 \mathrm{r}$ & & $\begin{array}{c}0.040 \\
(0.122) \\
\text { ns }\end{array}$ & $\begin{array}{c}-0.253 \\
(0.097) \\
* *\end{array}$ & $\Delta \operatorname{lnM} 1 \mathrm{r}$ & & & & $\Delta \operatorname{lnCashr}$ & \\
\hline$\Delta \operatorname{lnGDPr}$ & $\begin{array}{c}-0.261 \\
(0.117) \\
* *\end{array}$ & $\begin{array}{c}-0.261 \\
(0.120) \\
* *\end{array}$ & & $\Delta \operatorname{lnGDPr}$ & & & & 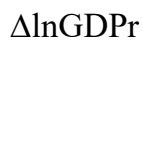 & $\begin{array}{c}-0.158 \\
(0.071) \\
* *\end{array}$ \\
\hline$\Delta \ln T B R$ & & & & $\Delta \ln \mathrm{TBR}$ & $\begin{array}{c}1.913 \\
(0.841) \\
* *\end{array}$ & $\begin{array}{c}2.846 \\
(0.880) \\
* * *\end{array}$ & & $\Delta \ln T B R$ & \\
\hline$\Delta \ln I n f$ & $\begin{array}{c}0.915 \\
(0.324) \\
* * *\end{array}$ & & & $\Delta \ln I n f$ & & & & $\Delta \ln I n f$ & \\
\hline$\Delta \ln E x c h$ & & & & $\Delta \operatorname{lnExch}$ & $\begin{array}{c}-0.095 \\
(0.098) \\
n s \\
\end{array}$ & $\begin{array}{c}-0.143 \\
(0.110) \\
n s\end{array}$ & $\begin{array}{c}0.232 \\
(0.081) \\
* * *\end{array}$ & $\Delta \ln E x c h$ & \\
\hline
\end{tabular}

\section{Stability of long-runrelations}

In order to verify the stability of long-run relations, the CUSUM and CUSUM2 tests of Brown, Durbin \& Evans (1975) are applied. These tests are based on the cumulative sum of recursive residuals and of the squared recursive residuals respectively. Graphically, if the plots of the CUSUM and the CUSUMS2 do not cross two 5\% significance level critical lines then the coefficients are said to be stable. The graphs below show CUSUM and CUSUM2 tests for ARDL models of M2, M1 and Cash. Although the Algerian economy remains highly vulnerable to external shocks, in a context of pro-budget deficit bias, the results of the CUSUM and CUSUM2 stability tests show that long-runmoney demand for M2 and M1 remains stable. However, these tests show that the long-run demand for cash is not stable in Algeria. 
Figure 5 / CUSUM for M2- BIC model

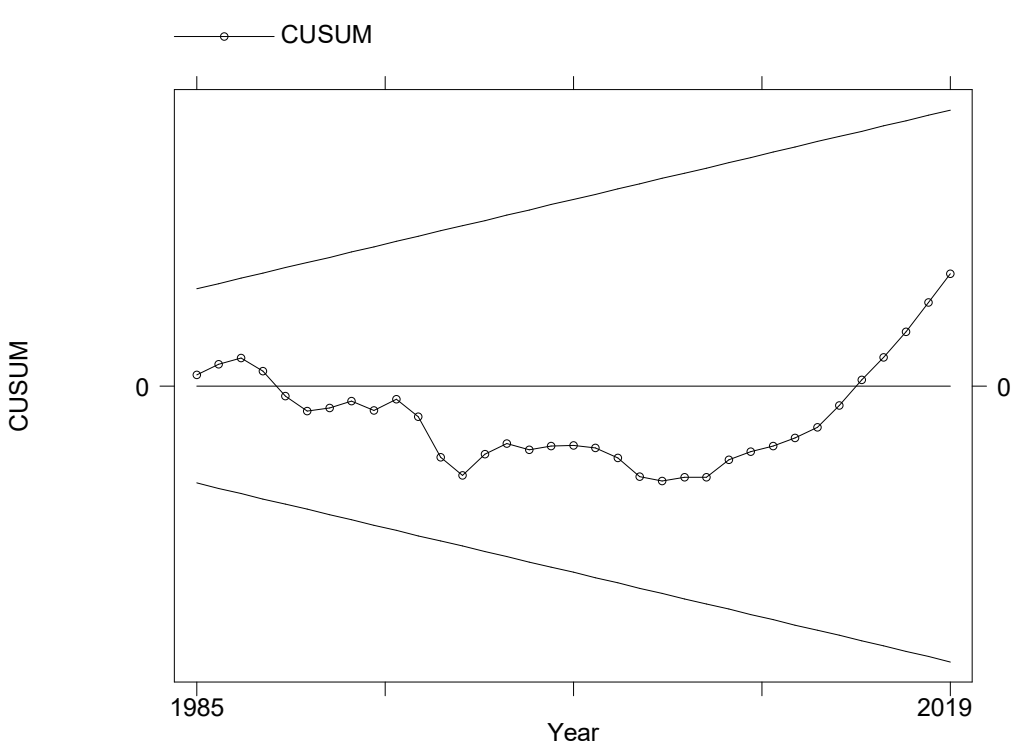

Figure 6/ CUSUM2 for M2 - BIC model

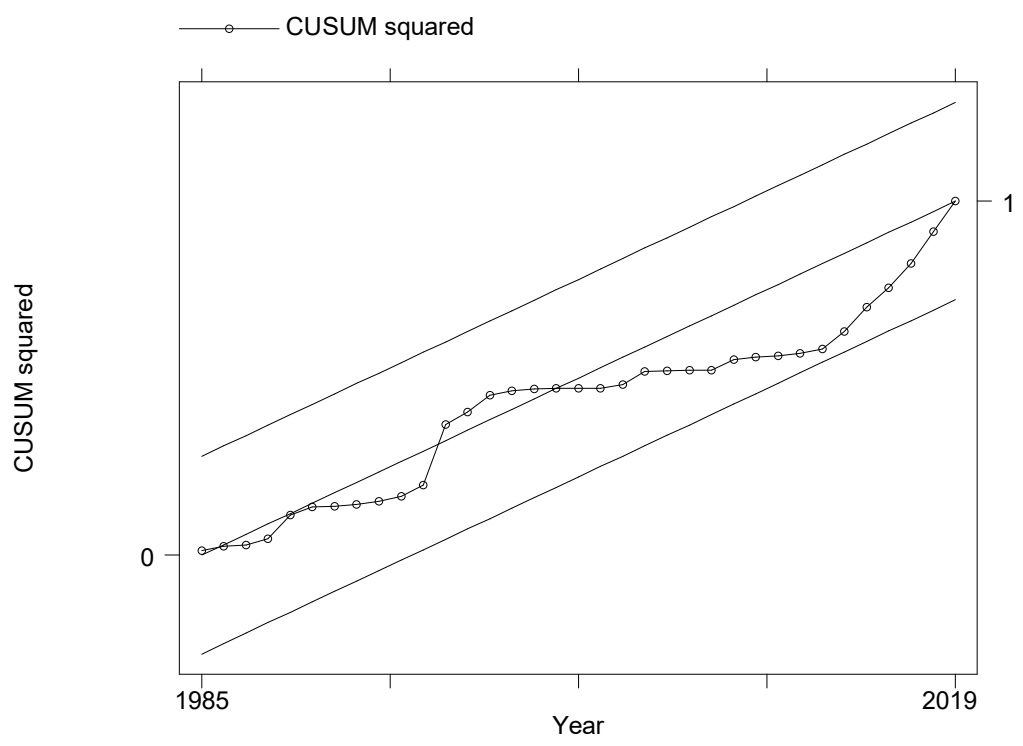


Figure 7/ CUSUM for M1- BIC model

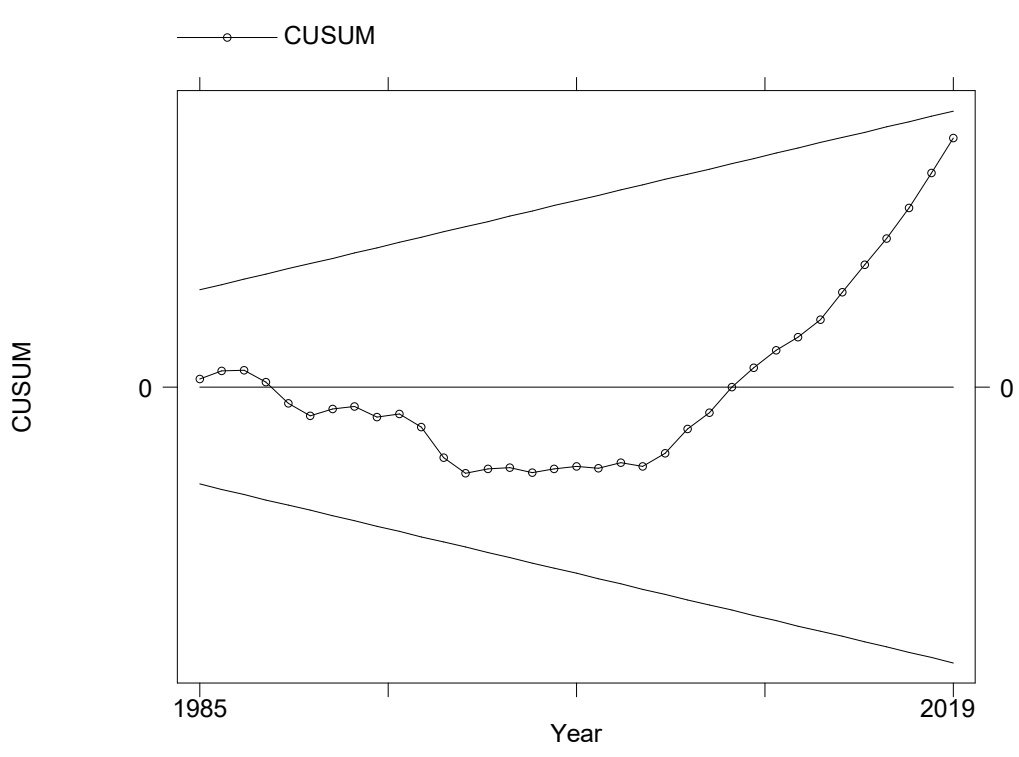

Figure 8/ CUSUM2 for M1- BIC model

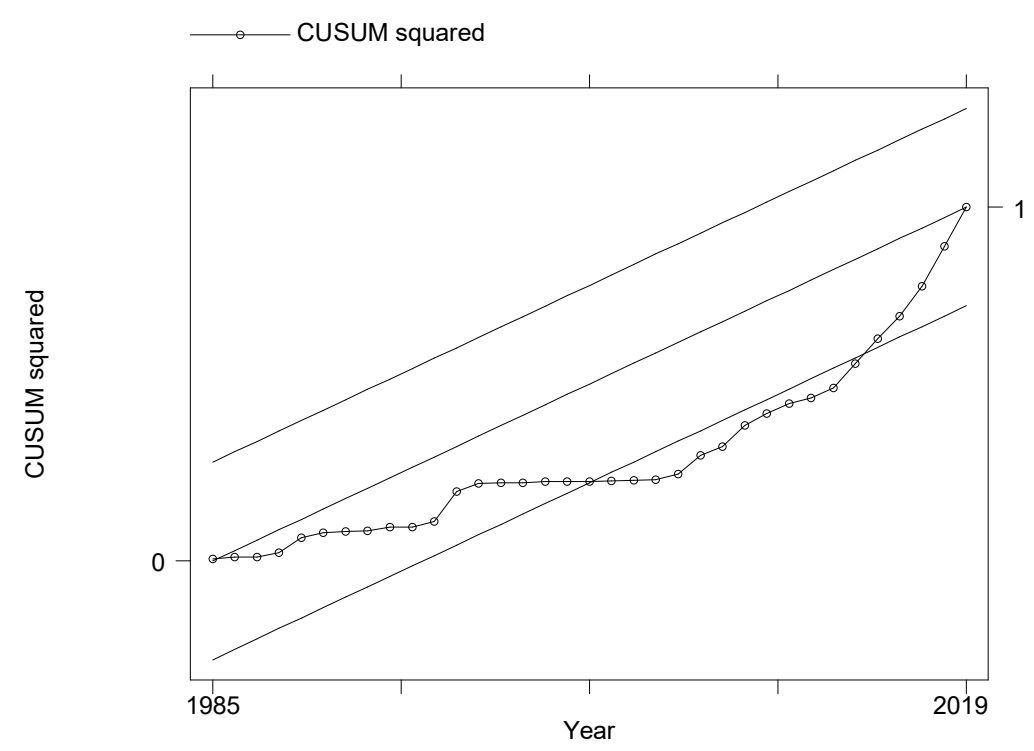


Figure 9/ CUSUM for Cash- BIC model

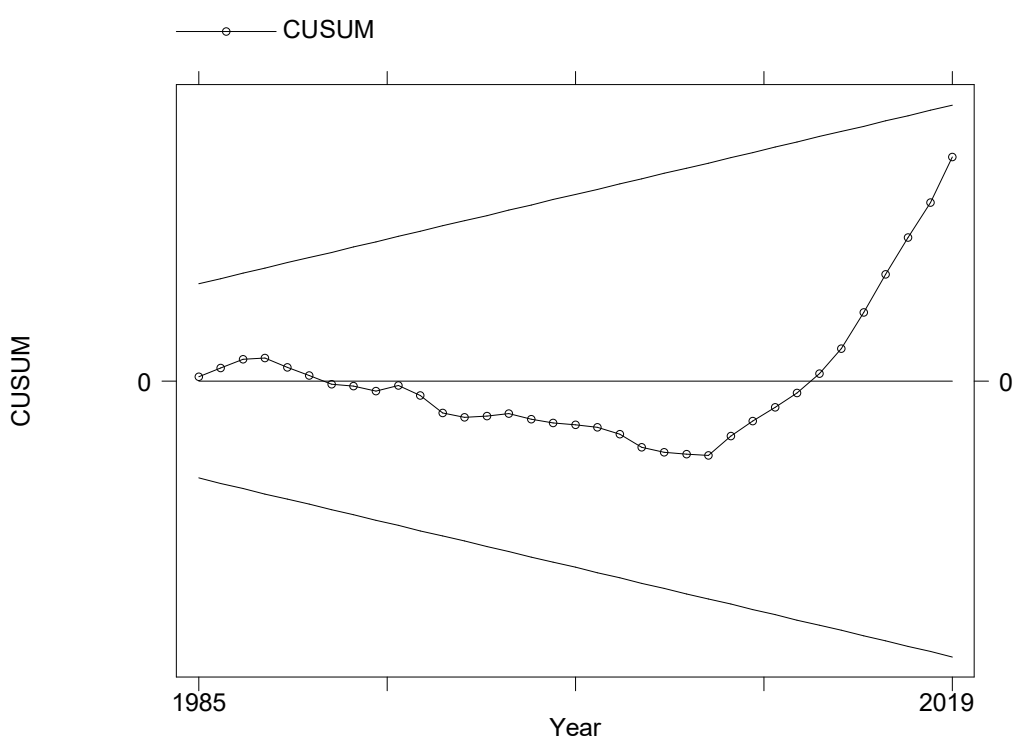

Figure 10/ CUSUM2 for Cash- BIC model

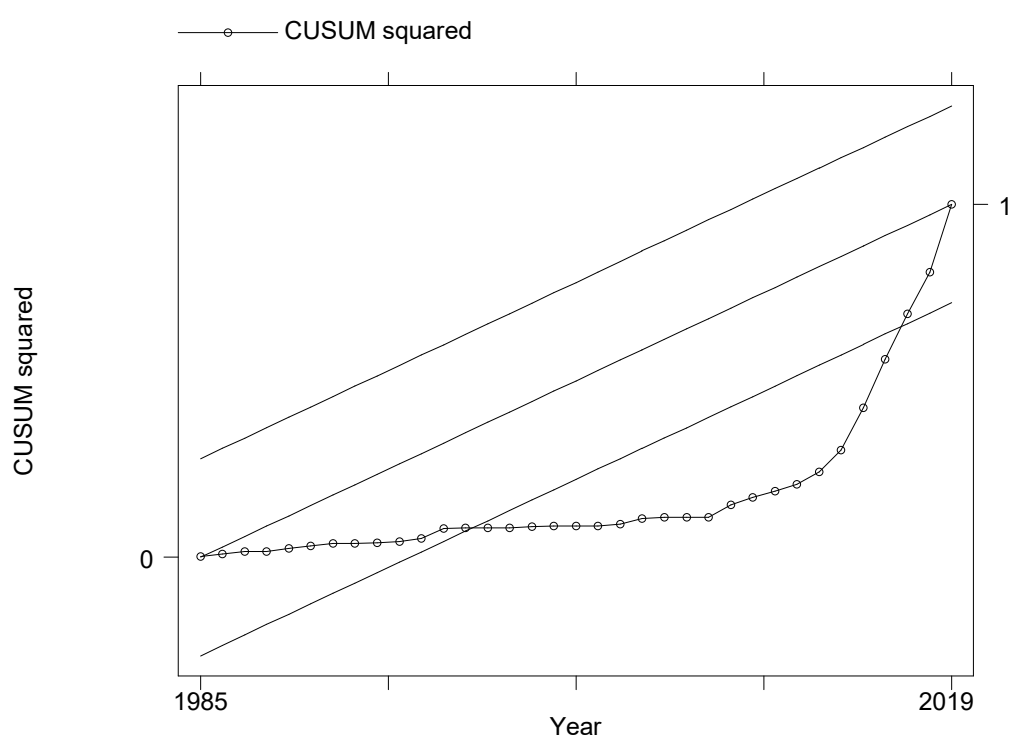

\section{Goodness of fit}

The adjusted coefficients of determination( $\left.\mathrm{R}_{\mathrm{a}}^{2}\right)$ for $\mathrm{M} 2, \mathrm{M} 1$ and Cash which are respectively $82.18 \%, 82.84 \%$ and $\underline{90.18} \%$ indicate a good quality of adjustmentwhich could also be appreciated through the comparison of graphs of observed data and fittedvalues for each aggregateat first difference (Rigures 11 to 13). 
Figure 11: Goodness of fit, M2

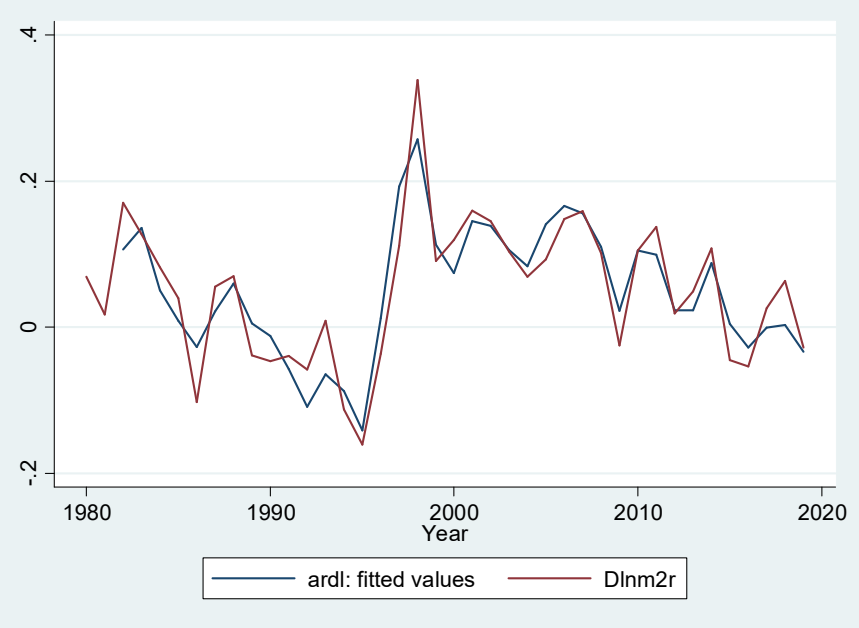

Figure 12: Goodness of fit, M1

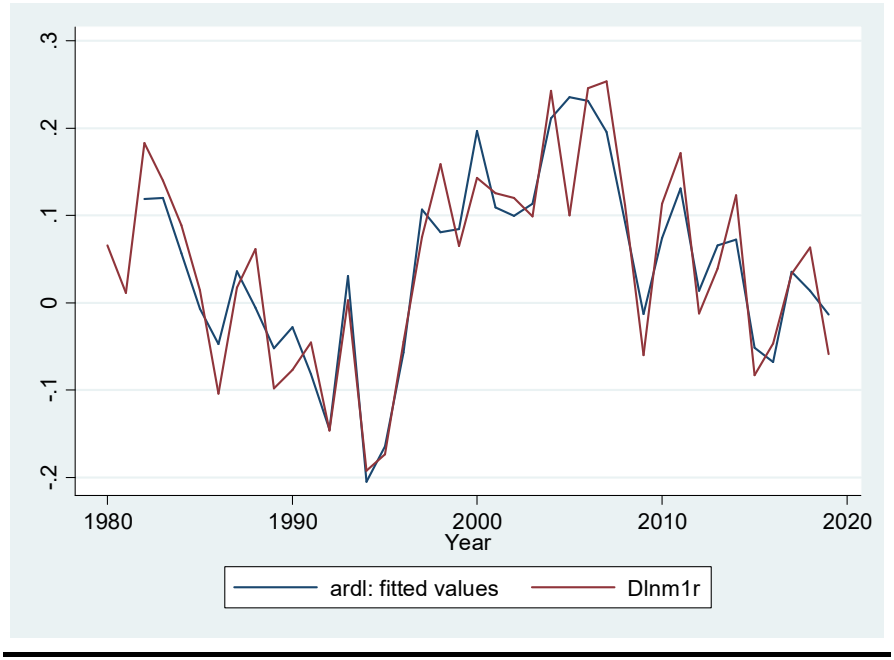

Figure 13: Goodness of fit, Cash

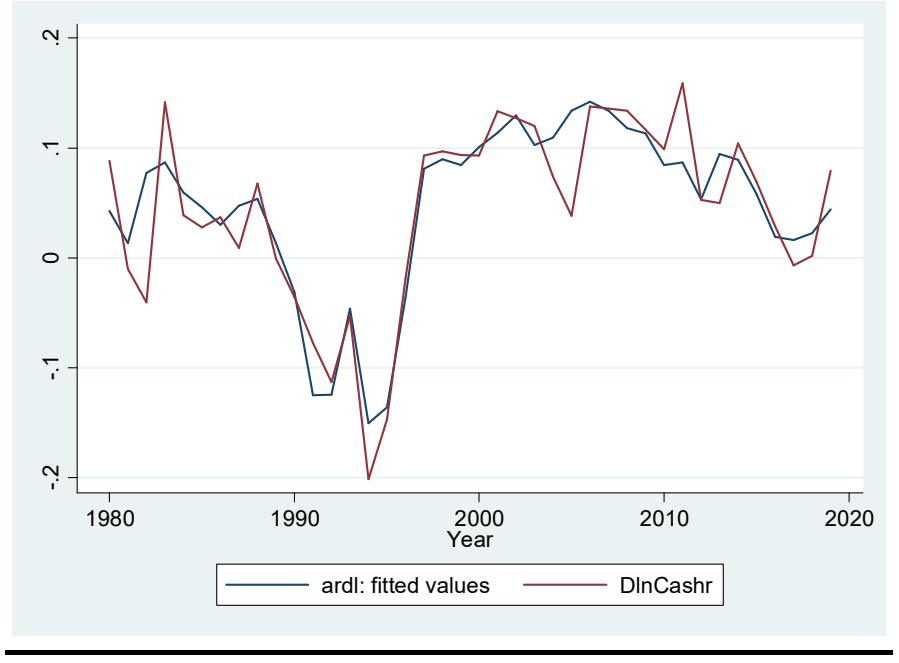




\section{How robust are the ARDL results?}

Globally, the long-term results seem to be robust and do not depend on the cointegration approach used. Indeed, both Johansen's trace and max statistics confirm the existence of cointegration relations between each aggregate and the regressors $\operatorname{lnGDPr}, \ln$ TBR and $\ln I n f$ and $\operatorname{lnExch}$ (see table 7).

Table 7/ Johansen's cointegration tests

\begin{tabular}{clccccccc}
\hline & max rank & Parms & LL & eigenvalue & trace statistic & cv 5\% & max statistic & cv 5\% \\
\hline M2 & 0 & 50 & 327.7518 &. & 84.296 & 59.46 & 42.439 & 30.04 \\
& 1 & 59 & 348.9713 & 0.67268 & 41.857 & 39.89 & 21.504 & 23.8 \\
& 2 & 66 & 359.7233 & 0.43215 & $20.3530^{*}$ & 24.31 & 13.7726 & 17.89 \\
& 3 & 71 & 366.6096 & 0.30402 & 6.5804 & 12.53 & 6.4955 & 11.44 \\
\hline M1 & 0 & 50 & 322.7732 &. & 103.2432 & 59.46 & 56.1161 & 30.04 \\
& 1 & 59 & 350.8312 & 0.77162 & 47.1271 & 39.89 & 26.6624 & 23.8 \\
& 2 & 66 & 364.1624 & 0.50423 & $20.4647^{*}$ & 24.31 & 14.7112 & 17.89 \\
& 3 & 71 & 371.518 & 0.321 & 5.7534 & $1253 \%$ & 5.668 & 11.44 \\
\hline Cash & 0 & 50 & 339.6125 &. & 83.0929 & 59.46 & 43.5054 & 30.04 \\
& 1 & 59 & 361.3652 & 0.68174 & $39.5875^{*}$ & 39.89 & 22.9908 & 23.8 \\
& 2 & 66 & 372.8606 & 0.45394 & 16.5967 & 24.31 & 12.589 & 17.89 \\
& 3 & 71 & 379.1552 & 0.282 & 4.0076 & 12.53 & 3.55 & 11.44 \\
\hline
\end{tabular}

Furthermore, as shown in Table 8 below, compared with the ARDL approach, results of the cointegration relationships for the money aggerates using Johansen VECM approach are fairly close. ${ }^{4}$ In particular, the estimated elasticities for the scale variable are precise and close to unity for both methods. All coefficients have identical signs and are significant except the coefficientof $\operatorname{lnTBR}$ for M2 aggregate in VECM approach. However, the speeds of adjustment for the ARDL approach seem to be somewhat faster for M1 and M2 models (about 8 months differences).

Table 8/ Long-term relation estimation from Johansen VECM approach

\begin{tabular}{llll}
\hline BIC & $\operatorname{lnM} 2 \mathrm{r}$ & $\operatorname{lnM1r}$ & LnCashr \\
\hline BIC & 2 lags & 2 lags & 2 lags \\
\hline noconstant & Coef. (Std. Err.) & Coef. (Std. Err.) & Coef. (Std. Err.) \\
\hline EC & $-0.353(0.081) * * *$ & $-0.272(0.079) * * *$ & $-0.126(0.032) * * *$ \\
\hline $\operatorname{lnGDPr}$ & $1.028(0.009) * * *$ & $1.044(0.012) * * *$ & $0.981(0.019) * * *$ \\
$\ln \mathrm{BBR}$ & $-0.171(0.807) \mathrm{ns}$ & $-3.320(1.024) * * *$ & $-5.70(1.479) * * *$ \\
$\ln \operatorname{lnf}$ & $-4.629(0.594) * * *$ & $-4.360(0.747) * * *$ & $-6.775(1.285) * * *$ \\
$\operatorname{lnExch}$ & $-0.081(0.021) * * *$ & $-0.205(0.027) * * *$ & $-0.129(0.040) * * *$ \\
\hline
\end{tabular}

\footnotetext{
${ }^{4}$ For Johansen approach, all VECM models are estimated with no constant and no trend.
} 


\section{Conclusion}

The study of long-run (1979-2019) money demand for M2, M1 aggregates and fiat currency, the subject of the present paper, concludes with statistically and economically relevant results that are potentially extremely useful in improving the conduct of monetary policy in the short and medium term.

Given the persistence of the external shock since 2014 and subsequent recourse since October 2017 to direct monetary financing by the Treasury (fiscal dominance for a period of five years), the Bank of Algeria must to some extent ensure price stability over the medium term, while stimulating the "credit channel" of monetary policy from 2021 onwards. To do so, its role as lender of last resort is henceforth decisive. In this context, the stability of money demand in terms of M2 and M1 is useful for the estimation of quantitative money and credit targets, consistent with the flexible inflation "targeting" exercise inherent in the reform of the monetary policy framework in 2010. However, the correlation of the M1 aggregate with the credit variable should be more relevant over the medium term than that of M2 money supply, especially if the deterioration in the situation of the hydrocarbon sector were to continue.

Furthermore, reaching the end of the monetary financing paradigm and following the effective implementation of "credit channel" reactivation from 2021 onwards, the relevance of the M2 aggregate can be seen to emerge as financial innovations are developed (Islamic finance, market financing, opening of the external capital account, etc.) and, as a result, the role of the interest rate would be more effective in running monetary policy. The M2 aggregate (excluding hydrocarbon deposits) remains significant both as a determinant of inflation and for the inflation forecasting exercise.

The scale of "cash" in the economy limits the scope for monetary policy, especially since the demand for fiat currency is proving to be unstable. The effectiveness of monetary policy being conducted through interest rates will, to some extent, suffer from this. If the period of fiscal dominance were to be extended beyond 2022, then the demand for fiat currency would require greater attention in the short to medium term.

Considering that the monetary behaviour of households and businesses has largely frustrated the objective of developing cashless payments over the last fifteen years, despite the establishment of modern payment mechanisms (RTGS and mass payment systems) that meet international standards, the necessary promotion of digital payments should be supported by more in-depth studies of demand for cash. The objective is also to provide a firm basis for financial inclusion through digital payment instruments that 
is sustained over the medium and long term so as to reinforce the role of monetary policy in the stabilisation process supported by adjustment of the dinar's exchange rate towards its equilibrium level.

\section{References}

Alvarez, F. \& Lippi, F. (2014). Persistent liquidity effects and long-run money demand. American Economic Journal: Macroeconomics 6 (2), 71-107 .

Bahmani, S. (2008). Stability of the Demand for Money in the Middle East. Emerging Markets Finance and Trade, 44(1), 62-83.

Bahmani-Oskooee, M., \& Barry, M. P. (2000). Stability of the demand for money in an unstable country: Russia. Journal of Post Keynesian Economics, 22(4), 619-629.

Bakhouche, A. (2006). Money demand in Algeria. Savings and Development, 221-246. Barigozzi, M., \& Conti, A. (2018). On the stability of the Euro area money demand and its implications for monetary policy. Oxford Bulletin of Economics and Statistics, 80, 755-787.

Baumol, W. J. (1952). The transactions demand for cash: An inventory theoretic approach. The Quarterly Journal of Economics, 545-556.

Bech, M. L., Faruqui, U., Ougaard, F., \& Picillo, C. (2018). Payments are a-changin'but cash still rules. BIS Quarterly Review, March.

Belongia, M.T. \& Ireland, P.N. (2019). A reconsideration of money growth rules. Boston College working papers in economics no. 976.

Benati, L., Lucas Jr, R. E., Nicolini, J. P., \& Weber, W. (2020). International evidence on long-run money demand. Journal of Monetary Economics.

\section{https://doi.org/10.1016/i.jmoneco.2020.07.003}

Ben Naceur, S., Ghazouani, S., \& Omran, M. (2008). Does stock market liberalization spur financial and economic development in the mena region? Journal of Comparative Economics, 36(4), 673-693.

Ben-Salha, O., \&Jaidi, Z. (2014). Some new evidence on the determinants of money demand in developing countries-A case study of Tunisia. The Journal of Economic Asymmetries, 11, 30-45.

Brown, R. L., Durbin, J., \& Evans, J. M. (1975) . Techniques for testing the constancy of regression relationships over time. Journal of the Royal Statistical Society: Series B (Methodological), 37(2), 149-163.

Cooley, T. F., \& LeRoy, S. F. (1981). Identification and estimation of money demand. The American Economic Review, 71(5), 825-844.

Davig, T. \&Leeper, E. (2007). "Generalizing the Taylor Principle". American Economic Review, 97 (3), 607-635.

Deadman, D. F. (1995). The demand for money in LDCs: empirical results. In Monetary Economics in Developing Countries (pp. 46-62). Palgrave, London. 
Engle, R. F., \& Granger, C. W. (1987). Co-integration and error correction: representation, estimation, and testing. Econometrica: Journal of the Econometric Society, 251-276.

Fiess, N., \& MacDonald, R. (2001). The instability of the money demand function : an I(2) interpretation. Oxford Bulletin of Economics and Statistics, 63, 475-495.

Goldfeld, S. M., Duesenberry, J., \& Poole, W. (1973). The demand for money revisited. Brookings Papers on Economic Activity, 1973(3), 577-646.

Granger, C. W. J. (1986). Developments in the study of cointegrated economic variables. Oxford Bulletin of Economics and Statistics, 48, 213-228.

Hetzel, R. L. (1984). Estimating money demand functions. Journal of Money, Credit and Banking, 16(2), 185-193.

Hoffman, D. L., \& Tahiri, C. (1994). Money demand in Morocco: Estimating long-run elasticities for a developing country. Oxford Bulletin of Economics and Statistics, 56(3), 305-324.

Johansen, S. (1988). Statistical analysis of cointegration vectors. Journal of Economic Dynamics and Control, 12(2-3), 231-254.

Johansen, S., \&Juselius, K. (1990). Maximum likelihood estimation and inference on cointegration-with appucations to the demand for money. Oxford Bulletin of Economics and Statistics, 52(2), 169-210.

Kripfganz, S., \& Schneider, D. C. (2018, September). ardl: Estimating autoregressive distributed lag and equilibrium correction models. In Proceedings of the 2018 London Stata Conference.

Koranchelian T. (2003), "Monetary Demand and Monetary Policy: Evidence from Algeria", (pp. 20-36), in Lazare et al. (2003), "Algeria: Selected Issues and Statistical Appendix", IMF, Middle Eastern Department, Country Report No. 03/69.

Laidler, D. (1979), The demand for money in the United States yet again.

Laidler, D. ., (1993), The Demand for Money: Theories, Evidence, and Problems (New York: HarperCollins College Publishers, 4th ed.).

Lucas Jr, R. E. (1988, January). Money demand in the United States: A quantitative review. In Carnegie-Rochester Conference Series on Public Policy (Vol. 29, pp. 137167). North-Holland.

Mankiw, N. G., \& Summers, L. H. (1986). Money demand and the effects of fiscal policies. Journal of Money, Credit and Banking, 18(4), 415-429.

Meltzer, A. H. (1963). The demand for money: The evidence from the time series. Journal of Political Economy, 71(3), 219-246.

Pesaran, M. H., \& Shin, Y. (1998). An autoregressive distributed-lag modelling approach to cointegration analysis. Econometric Society Monographs, 31, 371-413.

Pesaran, M. H., Shin, Y., \& Smith, R. J. (2001). Bounds testing approaches to the analysis of level relationships. Journal of Applied Econometrics, 16(3), 289-326. 
Sriram, M. S. S. (1999). Demand for M2 in an emerging-market economy: an errorcorrection model for Malaysia (No. 99-173). International Monetary Fund.

Sriram, S. S. (2000). A survey of recent empirical money demand studies. IMF Staff papers, 47(3), 334-365.

Tobin, J. (1956). The interest-elasticity of transactions demand for cash. The Review of Economics and Statistics, 241-247.

Tobin, J. (1958). Liquidity preference as behavior towards risk. The Review of Economic Studies, 25(2), 65-86.

Torvik, R. (2018). Oil prices and the exchange rate: Optimal monetary policy for oil exporting countries. In Arezki, R. et al. (Eds.), Rethinking the Macroeconomics of Resource-Rich Countries. CEPR Press.

Treichel, M. V. (1997). Broad money demand and monetary policy in Tunisia. International Monetary Fund. 